was actively pursued. The emphasis in the Depart. ment was changing-from static to dynamic biochemistry-never more so than in the special field of the amylases which has always claimed so much of Hopkins's time and interest. During and after the Second World War, nutritional investigations led to interest in yet another field - the vitamins of the B group, with special reference to their role in germination, malting and brewing processes, and their assay by microbiological means. An increasing preoccupation with microbiological chemistry has been observable in recent years and has resulted in useful studies in the nutrition of yeasts and bacteria. Prof. Hopkins may look back with some satisfaction on the achievements of a small department, limited in resources and with no possibility of team-work in the modern sense. Should the rumoured expansion of biochemistry in Birmingham be achieved, the Department may look forward with confidence to yet a third epoch.

\section{Imperial College of Science and Technology, London}

THE Imperial Colloge of Science and Technology has now completed the first stage of the massive expansion being undertaken at the request of the Government. The plan, announced in 1953, is to double the size of the College to accommodate three thousand students of science and engineering. There are now 2,240 students at the College, 36 per cent more than in 1953. The number of teaching staff now stands at three hundred-a rise of 33 per cent. Twenty-seven new posts as professor or reader in the University of London have been established at the College and have been filled. They cover a wirie range of subjects, from aeronautical structures, applied geophysics, instrument technology, parasitology and soil mechanics to nuclear power. A new building for aeronautics and chemical engineering is already partly in use, and will be in full operation in two months time. By this, by a reconstruction of the Students' Union and by a number of other building projects, the College has already added 20 per cent to its gross floor space. Work has now been started on the preparation of sites for large new buildings for engineering and physics.

\section{University of Leeds}

THE following have been appointed to lectureships in the University of Leeds: N. Brook (colliery engineering), Dr. A. J. Manuel (physics), J. McFarlane (mining and mine surveying), A. Peck (mine surveying), and Dr. J. E. Saxton (organic chemistry). The title of visiting professor in the University has been conferred upon Prof. Darrell Pratt, of the University of Florida, who will be working with Prof. F. C. Happold in the Department of Biochemistry during the session 1956-57. The following gifts, among others, have been received by the

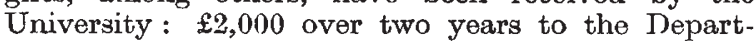
ment of Inorganic and Structural Chemistry from Imperial Chemical Industries, Ltd., for work on vanadium pentoxide systems; $£ 500$ a year for three years to the Department of Physical Chemistry from the Distillers Company, Ltd., for the support of research; $£ 1,000$ to the Department of Civil Engineering from the Steelwork Society for research into stress distribution of high-tensile bolted structural connexions; $£ 3,000$ for $1955-56$ to the Department of Mining from the National Coal Board (North. Eastern Division) ; $£ 2,000$ for $1955-56$ to the Department of Coal Gas and Fuel Industries from the Gas
Plant Manufacturers' Development Council ; $£ 1,350$ to the Department of Textile Industries from Courtaulds, Ltd.; $\$ 9,000$ over three years to the Departments of Medical Physics and Radiology and Radiotherapy from the Nuffield Foundation, for research on the intensification of X-ray fluorescent screen images.

The total number of full-time students registered at the University of Leeds is now 3,731, which is some 200 more than at the corresponding date last session ; of this increase, at least two hundred are in the Faculties of Science and Technology. The new admissions are about 180 more than at the corresponding date last session ; $60-70$ of these are on the arts side and about 120 in science and technology.

\section{Royal Society of Edinburgh : Officers for 1956-57}

Tue following have been appointed to the Council of the Royal Society of Edinburgh for the session 1956-57: President, Prof. James Ritchie; Vice. Presidents, Prof. J. Norman Davidson, Principal H. B. Nisbet, Prof. Meirion Thomas, Prof. A. C. Aitken, Dr. J. E. Richey, Prof. D. Whitteridge; General Secretary, Prof. Norman Feather; Secretaries to Ordinary Meetings, Dr. T. R. Bolam and Dr. A. W. Greenwood; I'reasurer, Mr. A. IV. Young; Curator of Library and Museum, Dr. Douglas Guthrie; Councillors, Prof. E. L. Hirst, Dr. D. E. Rutherford, Dr. D. A. Allan, Prof. G. H. Bell, Dr. D. N. MeArthur, Dr. A. G. MacGregor, Prof. C. H. Waddington, Dr. J. A. Macdonald, Dr. J. R. Peddie, Dr. R. Schlapp, Dr. J. B. Tait and Prof. G. M. Wyburn.

\section{Metallurgical Reviews : a New Quarterly Journal}

To all those concerned with any aspect of metallurgy, the appearance of a new quarterly periodical, Metallurgical Reviews (members of the Institute of Metals, 32s. $6 d$. or 5 dollars per year ; non-members, $42 s$. or 6.50 dollars), will be of more than usual interest. Although published by the Institute of Metals, the interest; of which lie in the field of nonferrous metallurgy, the new publication will cover the whole field with the exception of mining, the extraction of metals from their ores, and practice in iron and steel works. It is intended that these reviews should be of a comprehensive and critical nature, and relate both to the industrial and the theoretical aspects of the subject. The four reviews contained in the first issue (pp. 156) fully satisfy these conditions. Prof. J..J. Trillat (Sorbonne, Paris) has written on the metallurgical aspects of microradiography; Prof. C. R. Soderberg (Massachusetts Institute of Technology) on mechanical properties in relation to design requirements ; D. M. Lewis (Aluminium Laboratories, Ltd.) on the principles of continuous casting of metals; and B. E. Hopkins (National Physical Laboratory, Teddington) on the preparation and properties of high-purity iron. All these are valuable compilations, very well prepared and illustrated, and on the average some sixty references are given to each section of the work. The Council of the Institute of Metals is to be congratulated on performing a most valuable service to those concerned with both the technology and the theory of metallurgy.

\section{Two New Scottish Nature Reserves}

Thr Scottish Committee of the Nature Conservancy has recently established new nature reserves at Inchnadamph, Sutherland, and Glen Diomhan, Bute. The former consists of 3,200 acres south-east 